\title{
ANALYSIS OF STUDENTS' MATHEMATICAL COMMUNICATION IN DRAWING GRAPHS OF MULTIVARIABLE FUNCTIONS
}

\author{
Ratna Yulis Tyaningsih $^{1^{*}}$, Arjudin ${ }^{2}$, Nurul Hikmah ${ }^{3}$ \\ ${ }^{1,2,3}$ Department of Mathematics and Education, Faculty of Teacher Training and Education, \\ Universitas Mataram, Indonesia
}

*Corresponding author: ratnayulis@unram.ac.id

\begin{tabular}{|c|c|}
\hline Article Info & ABSTRACT \\
\hline Article history: & \multirow{6}{*}{$\begin{array}{l}\text { Mathematical communication competencies help students to } \\
\text { convey mathematical ideas orally and in writing. The purpose of } \\
\text { this study was to analyze students' communication skills in drawing } \\
\text { graphs of multivariable functions in advanced calculus courses. } \\
\text { This type of research is qualitative with descriptive methods. The } \\
\text { subjects in this study were } 28 \text { students of Mathematics Education } \\
\text { class } 4 \mathrm{~B} \text {. This study used a stratified random sampling technique to } \\
\text { obtain } 3 \text { students consisting of high, medium, and low mathematics } \\
\text { competencies. The data collection instruments used were the } \\
\text { competency mapping test, evaluation test, and interview guidelines. } \\
\text { The results of this study are (1) students with high competence } \\
\text { excel at writing and making mathematical models, (2) students with } \\
\text { moderate competence have advantages in three stages, but there are } \\
\text { few errors in applying the agreement, (3) students with low } \\
\text { competence make mistakes at the third stage due to wrong in } \\
\text { formulating problems and designing problem-solving strategies. }\end{array}$} \\
\hline Received: October 29, 2020 & \\
\hline $\begin{array}{l}\text { Accepted: November 15, } \\
2020\end{array}$ & \\
\hline $\begin{array}{l}\text { Published: November 30, } \\
2020\end{array}$ & \\
\hline Keywords: & \\
\hline $\begin{array}{l}\text { Advanced calculus } \\
\text { Graphs of multivariable } \\
\text { functions } \\
\text { Mathematical communication }\end{array}$ & \\
\hline
\end{tabular}

\section{ANALISIS KOMUNIKASI MATEMATIS MAHASISWA DALAM MENGGAMBAR GRAFIK FUNGSI MULTIVARIABEL}

\author{
Kata Kunci: \\ Kalkulus lanjut \\ Grafik fungsi multivariable \\ Komunikasi matematis
}

\begin{abstract}
ABSTRAK
Kompetensi komunikasi matematis membantu siswa untuk menyampaikan gagasan matematika secara lisan maupun tulisan. Tujuan penelitian ini adalah menganalisis keterampilan komunikasi siswa dalam menggambar grafik fungsi multivariabel pada mata kuliah kalkulus lanjut. Jenis penelitian ini adalah kualitatif dengan metode deskriptif. Subjek dalam penelitian ini adalah mahasiswa Pendidikan Matematika kelas 4B berjumlah 28 siswa. Penelitian ini menggunakan teknik stratified random sampling diperoleh 3 siswa terdiri dari kompetensi matematika tingkat tinggi, sedang, dan rendah. Instrumen pengumpulan data yaitu tes pemetaan kompetensi, tes evaluasi, dan pedoman wawancara. Hasil penelitian ini adalah (1) siswa dengan kompetensi tinggi unggul pada tahap menulis dan membuat model matematika, (2) siswa dengan kompetensi unggul dalam tiga tahap dengan sedikit kesalahan prosedur, (3) siswa dengan kompetensi rendah lemah dalam ketiga tahap karena salah dalam merumuskan masalah awal dan memilih strategi pemecahan masalah yang tepat.
\end{abstract}




\section{INTRODUCTION}

Mathematics learning activities include the deliberate exchange of ideas through classroom discussions through verbal, visual, and written communication. Classroom activities provide opportunities for students to share ideas, clarify understanding, build arguments, develop language to express mathematical ideas, and learn to see things from another perspective. [1] [2]. Such learning activities will support the development of student communication skills as stated in the principles of NCTM which consists of five standard processes, namely problem solving, reasoning and evidence, communication, connection, and representation [3]. Two reasons make communication skills in mathematics important for students to have, namely (1) mathematics as a language, meaning that mathematics is not only a tool for thinking, finding patterns, solving problems, or drawing conclusions but also as a tool in communicating ideas be precise, and careful and (2) mathematics learning as a social activity, meaning that learning mathematics is a social activity, namely a tool for interaction between students and between teachers and students [4] [5] [6] [7].

Mathematical communication helps students convey mathematical ideas both orally and in writing which can be developed through the learning process of mathematics [8]. Mathematical communication is concerned with (1) connecting real objects, pictures, tables, formulas, and diagrams into mathematical ideas, (2) explaining mathematical ideas orally or in writing through real objects, pictures, graphics, and algebra; (3) states daily problems in a mathematical model; (4) discuss and write down mathematical symbols; (5) understanding the material, making conjectures, compiling arguments, formulating and generalizing patterns; (6) formulate questions about mathematics [9][8][10]. One of the appropriate materials to support this competency is drawing a graph of multivariable functions in advanced calculus courses. In drawing graphics, students can represent their creative ideas through pictures, diagrams, formulas, or by presenting their ideas/opinions in front of the class.

Students who have good mathematical communication skills can solve mathematical problems, construct their knowledge, then can convey it to others in a clear and structured manner [17]. The measurement of mathematical communication skills is based on the aspects of writing, making mathematical models, and drawing [18]. In the writing aspect, students are asked to write down answers in their language, conveying clear, logical, and systematic explanations. In the aspect of making mathematical models, students must be skilled at making mathematical models of the questions given, operating the algebraic form obtained, and performing proper calculations. Furthermore, in the drawing aspect, students can draw graphs, diagrams, pictures, or tables accompanied by clear diagram components to help students represent their ideas.

Mathematical communication uses language and symbols to communicate mathematical ideas so that students can (1) reflect on learning independently and explain their thinking logically; (2) formulating new concepts by developing existing concepts through discovery and investigation; (3) express their ideas either orally or in writing; (4) understanding mathematics material through a lot of reading; (5) ask the extent of their mathematical knowledge; (6) assesses the flexibility of using mathematical notation and its role in developing mathematical ideas [19] [20]. Giving challenges to students to communicate orally or in writing can help deepen understanding of mathematical concepts that have been learned, improve performance/performance in presenting information, and reduce student anxiety in dealing with math problems [21][22]. 
Based on the results of the researchers' observations about the student's communication skills are still low in solving multivariable function graph problems as shown in Figure 1.

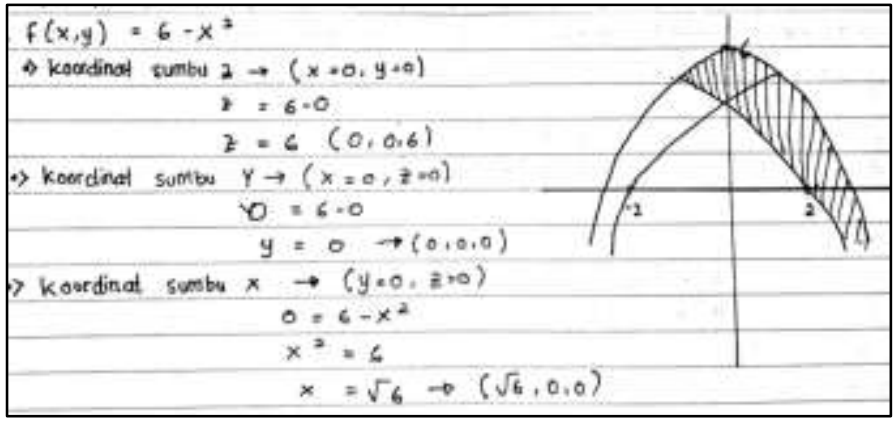

Figure 1. Student Answers during Observations

Figure 1 shows that students are still unable to construct their knowledge in drawing graphs of multivariable functions which is proven by students still thinking about cartesian diagrams in two-dimensional space. The student cannot describe the $\mathrm{x}$-axis, $\mathrm{y}$-axis, and zaxis in three-dimensional space. Then the chosen strategy is also not properly used so that the wrong answer is obtained. Thus, it is necessary to communicate to students through indepth interviews to find out what they are thinking and taking in this way so that scaffolding can be done to improve student thinking.

Other research about the weakness of student mathematical communication can be overcome by applying project-based learning, problem-based learning model, and combining it with collaborative learning [12] [13] [14] or using the video-tracker analysis to measure communication skills [15]. Other studies use the Cabri 3D application to overcome the communication limitations of students [16]. This is similar to this research which uses a similar application, namely Geogebra 3D, but the difference lies in the provision of scaffolding in the form of in-depth interviews to explore more students' knowledge about what they think and why they choose this strategy.

\section{METHOD}

The purpose of this study was to analyze students' communication skills in drawing graphs of multivariable functions in advanced calculus courses. This research approach is qualitative with a descriptive method. The descriptive method is a research method that describes a scientific condition or condition by describing it [23]. The research was conducted in the 2019/2020 academic year at the University of Mataram. The research subjects chosen were students of Semester 4 Mathematics Education for the 2019/2020 academic year who took the Advanced Calculus course totaling 28 students. Then 3 students were taken based on the calculation of their mathematical ability levels as presented in Table 1.

Table 1. Students' Mathematical Ability Level

\begin{tabular}{cc}
\hline Ability Level & Value Range \\
\hline High & $x \geq$ mean $+\mathrm{SD}$ \\
Moderate & mean $-\mathrm{SD}<x<$ mean $+\mathrm{SD}$ \\
Low & $x \leq$ mean $-\mathrm{SD}$ \\
\hline
\end{tabular}




\section{Information:}

$x \quad=$ score of the mathematical ability of each student

Mean $=$ average score of students' mathematical ability

$\mathrm{SD} \quad=$ standard deviation of students' mathematical ability scores

In detail, this research procedure can be seen in Figure 2.

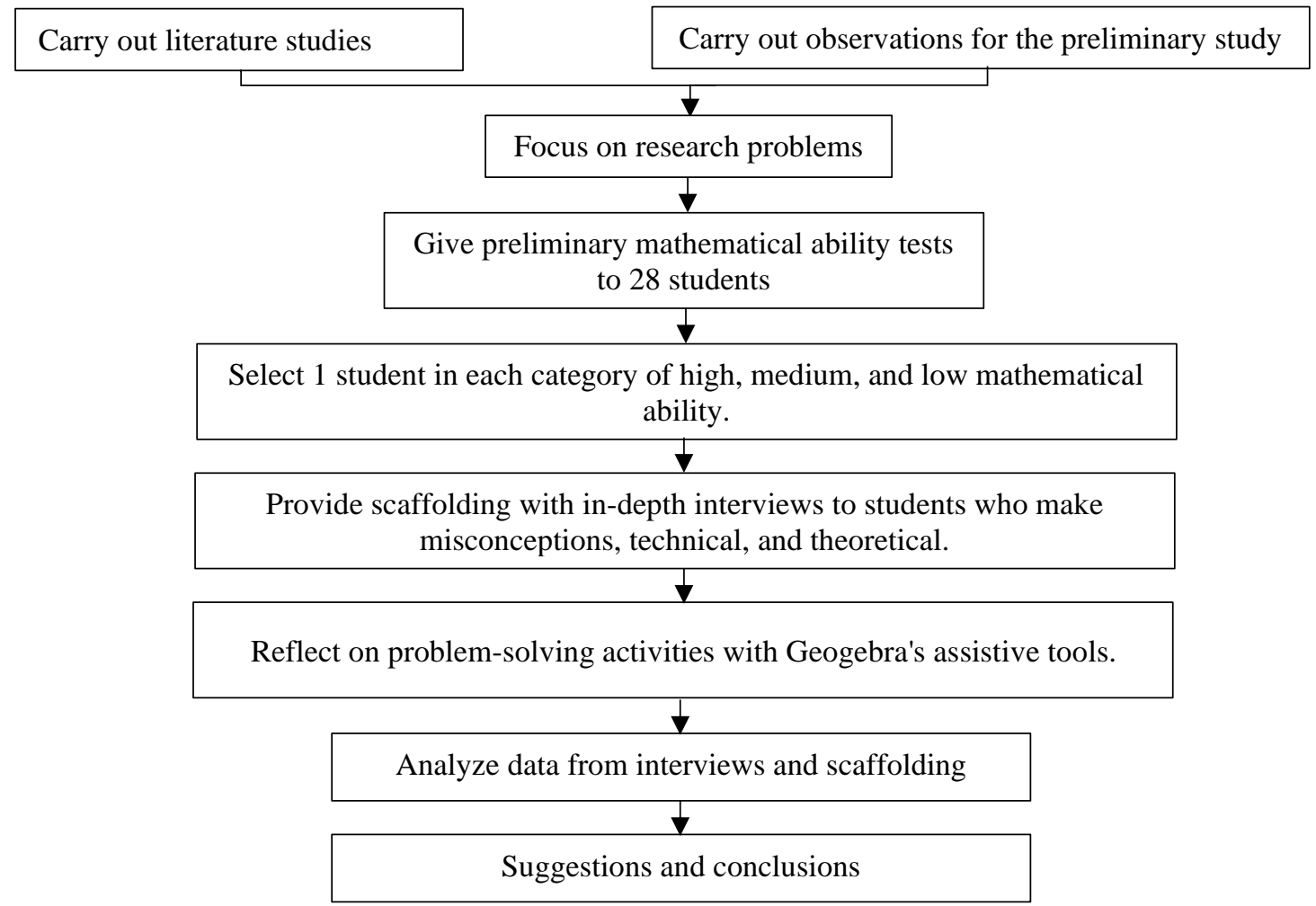

Figure 2. Flowchart of Research Procedures

Activities undertaken include the selection of research subjects, giving test questions, and online interviews. Indicators of students' mathematical communication skills in drawing graphs of multivariable functions are presented in Table 2.

Table 2. Indicator of Mathematical Communication Ability

\begin{tabular}{|c|c|c|}
\hline Aspect of Ability & Indicator & Score \\
\hline \multirow[t]{4}{*}{ Writing } & $\begin{array}{l}\text { Provide explanations in a systematic, correct, clear, reasonable, and } \\
\text { logical manner. }\end{array}$ & 4 \\
\hline & $\begin{array}{l}\text { Provide a mathematical, reasonable, and correct explanation even } \\
\text { though it is not logically arranged or there is a language error. }\end{array}$ & 3 \\
\hline & $\begin{array}{l}\text { Provides a mathematical and logical explanation, but is only partly } \\
\text { correct }\end{array}$ & 2 \\
\hline & Most of the explanations are wrong & 1 \\
\hline \multirow{4}{*}{$\begin{array}{l}\text { Making } \\
\text { mathematical } \\
\text { models }\end{array}$} & $\begin{array}{l}\text { Make mathematical models and perform calculations correctly to obtain } \\
\text { the correct solution. }\end{array}$ & 4 \\
\hline & $\begin{array}{l}\text { Make a mathematical model correctly, but there is a calculation error so } \\
\text { that the wrong solution is obtained }\end{array}$ & 3 \\
\hline & $\begin{array}{l}\text { Wrong in making a mathematical model so that the wrong solution is } \\
\text { obtained }\end{array}$ & 2 \\
\hline & $\begin{array}{l}\text { The answer does not lead to what was asked in the question or the answer } \\
\text { is not clear. }\end{array}$ & 1 \\
\hline
\end{tabular}


Drawing

Draw graphics correctly and be accompanied by complete explanations.

Draw a graphic with a few errors in writing down how to solve it.

\section{RESULTS AND DISCUSSION}

The results of this study indicate that the research subjects in drawing multivariable graphs have various mathematical communication skills. The diversity of mathematical communication skills possessed by students shows the level of student understanding of the Multivariable Function material.

Based on the mapping of mathematical abilities of 4A students using the formula presented in Table 1, there are 12 students with high mathematical ability categories, 11 students with moderate mathematical ability categories, and 5 students with low mathematical ability categories. Furthermore, 3 students were selected from each level to represent each category of student mathematical ability. A discussion of mathematical communication skills from each category of mathematical abilities can be stated as follows.

\subsection{Mathematical Mommunication Skills Obtained from The Subject of High Mathematical Abilities}

The description of students' mathematical communication skills with mathematical communication skills can be shown through 3 indicators, namely writing, making mathematical models, and drawing.

$z=2 x+3 y$
$\Rightarrow$ Perpotongan dengan sumbu
$x=0, y=0, z=0 \quad(0,0,0)$
$\rightarrow$ Perpotongan ding sumbu $x=0, y=0$
$z=2(0)+3(0)$
$=0 \quad(0,0,0)$
$\Rightarrow$ Perpotongan dng sumbu $x=1, y=1$
$z=2.1+3.1 \quad(1,1,5)$
$=5$
$\Rightarrow$ perpotongan dng sumbu $x=1, y=0$
$z=2.1+3.0 \quad(1,0,2)$
$z=2$

Figure 3. M1's Answer at The Writing Stage

Figure 3 shows that M1 at the writing stage can correctly identify the problem by what is known and asked about the questions. M1 chooses the right strategy in solving the problem, namely by finding 4 coordinates of the points $(x, y, z)$ through substitution to $z=2 x+3 y$. However, M1 does not understand the definition of the axes, M1 writes the intercepts of the $x=1$ and $y=1$ axes. So that M1 says $x=1$ and $y=1$ are axes, in other words, M1 cannot yet distinguish which ones are axes and not axes. 
$\mathrm{R}$ : What do you know from question number 1 ?

M1 : There is a multivariable function $z=2 x+3 y$. Then I was asked to draw the graph.

$\mathrm{R} \quad$ : What strategy did you choose?

M1 : I'm looking for points that intersect the x-axis, $y$-axis, and z-axis to help me draw the graph.

$\mathrm{R}$ : Which do you mean by the intersection of the axes?

M1 : The point $(0,0,0)$ is the intersection of the $\mathrm{x}=0$ axis, $\mathrm{y}=0$ and $\mathrm{z}=0$. Then the point $(1,1,5)$ is the intersection of the $\mathrm{x}=1$ and $\mathrm{y}=1$ axes and the point $(1,0,2)$ is the intersection of the $\mathrm{x}=1$ and $\mathrm{y}=0$ axes.

$\mathrm{R}$ : Try to distinguish which is the axis and not the axis? In three dimensional space, there are $\mathrm{x}$-axis, $\mathrm{y}$-axis, and $\mathrm{z}$-axis, try to be careful ... are $\mathrm{x}=1$ and $\mathrm{y}=1$ the axes?

M1 : Ooo ... yes ma'am ... $\mathrm{x}=1$ and $\mathrm{y}=1$ are not axes. Maybe $\mathrm{x}=0, \mathrm{y}=0$ and $\mathrm{z}=0$ which are the axes because if they are drawn coinciding with the axis lines.

$\mathrm{R}$ : Okay ... that's right ... the strategy you chose is correct but you have to be careful when writing down how to solve it.

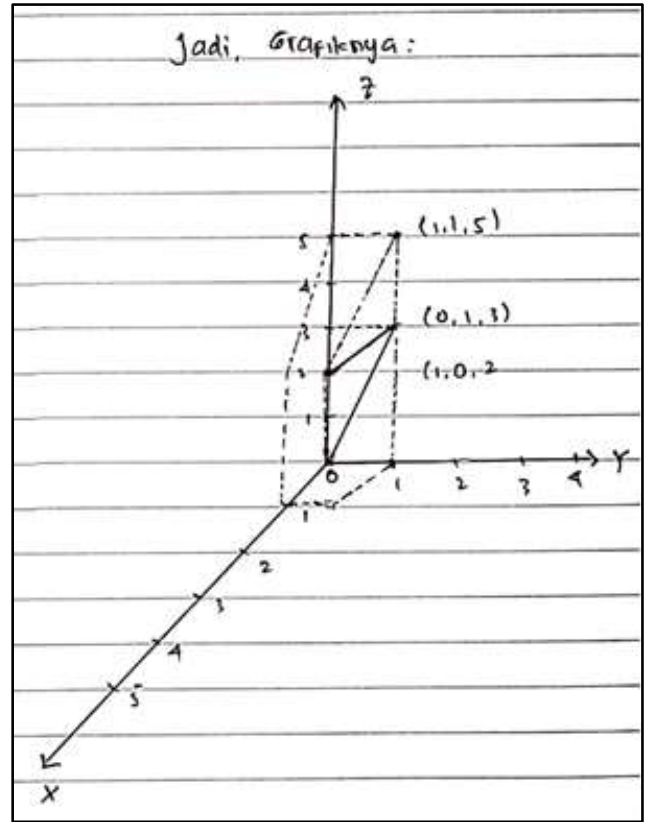

Figure 4. M1's Answer at The Drawing Stage

Figure 4 shows that M1 has implemented the strategy chosen to draw the graph. Next, M1 plots the coordinates of the points obtained, namely points $(0,0,0),(1,1,5)$, and $(1,0,2)$. However, there is a new point that is plotted in the three-dimensional space without any prior explanation at the writing stage and creating a mathematical model, namely point $(0,1,3)$. However, if checked again with the substitution to $z=2 x+3 y$, this point satisfies the equation. At the drawing stage, M1 made a mistake in plotting points (1, $0,2)$ and points $(1,1,5)$. Thus, the final answer from M1 is still wrong because it is wrong in plotting points $(1,0,2)$ and points $(1,1,5)$ so that the graphical image obtained is also wrong. The stage of making a mathematical model can be seen from M1's answer in Figure 1 and Figure 2. M1 can write the mathematical model correctly and perform algebraic 
operations correctly. M1 can substitute the selected points to $z=2 x+3 y$ then plot the points and are connected to form a function graph.

$\mathrm{R} \quad$ : What are the first steps you take when drawing charts?

M1 : First draw the $\mathrm{x}$-axis, $\mathrm{y}$-axis, and $\mathrm{z}$-axis lines complete with the diagram components.

$\mathrm{R} \quad$ : OK good. How do you plot the points?

M1 : If point $(0,0,0)$ is right in the middle, while point $(1,1,5)$ starts by shifting 1 unit from 0 to 1 on the $\mathrm{x}$-axis. Then it is shifted 1 unit to the right parallel to the $\mathrm{y}$-axis then shifted upward 5 units parallel to the $\mathrm{z}$ axis.

$\mathrm{R}$ : Take a look back at your picture, is it by the steps that you have revealed earlier?

M1 : Ohh ... yes ma'am, I'm in a hurry

\subsection{Mathematical Communication Skills Obtained from The Subject of Moderate Mathematical Abilities}

The second subject in this study was a student with moderate mathematical ability, namely M2. Furthermore, the mathematical communication skills possessed will be analyzed at the writing, drawing, and writing stages of mathematical models. M2's answer at the writing stage is presented in Figure 5.

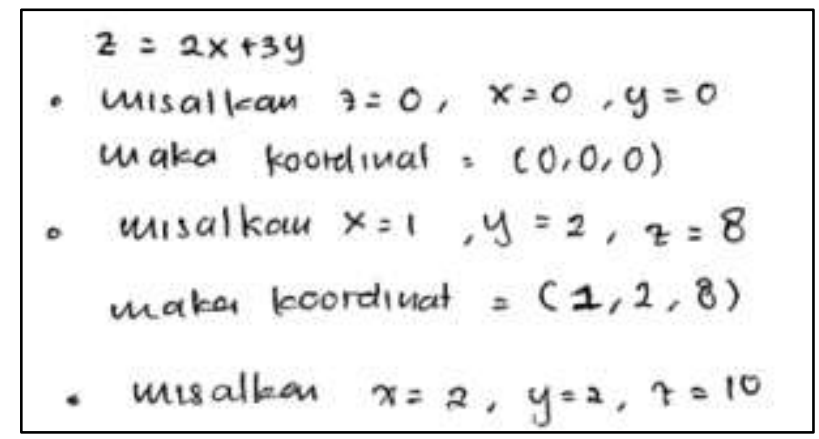

Figure 5. M2's Answer at The Writing Stage

Figure 5 shows that at the writing stage, M2 can already identify the problem well. This is shown by writing and the M2 interview results in writing down what was known and asked in the questions. However, at the stage of writing the mathematical model, M2 did not write down the complete completion procedure. It is shown from M2 not writing the substitution process for several points obtained. M2 also did not check the points obtained, but overall M2 did not make any mistakes in the calculation. M2's answer at the drawing stage is presented in Figure 4.

$\mathrm{R}$ : What do you know about question no.1?

M2 : In the problem, the function $\mathrm{z}=2 \mathrm{x}+3 \mathrm{y}$ has been given then I was asked to describe the graph.

$\mathrm{R}$ : How do you solve it?

M2 : I took several points and then substituted them for the equation $z=2 x+$ $3 y$.

$\mathrm{R} \quad$ : What do you gain from taking these points?

M2 : I obtained 3 points that fulfill the equation, namely points $(0,0,0),(1,2$, $8)$, and $(2,2,10)$.

298 Indonesian Journal of Science and Mathematics Education 
$\mathrm{R}$ : Have you checked the 3 points? Do all of them fulfill the equation $\mathrm{z}=2 \mathrm{x}$ $+3 \mathrm{y}$ ?

M2 : I haven't checked yet ... (I'll check for a while)

Everything is correct ma'am ... has fulfilled the equation $\mathrm{z}=2 \mathrm{x}+3 \mathrm{y}$.

$\mathrm{R} \quad$ : OK ... make it a habit to check your answer again. To make it easier to check these points, also make it a habit to write down the complete answer, including the process when substituting each of these points into the equation.

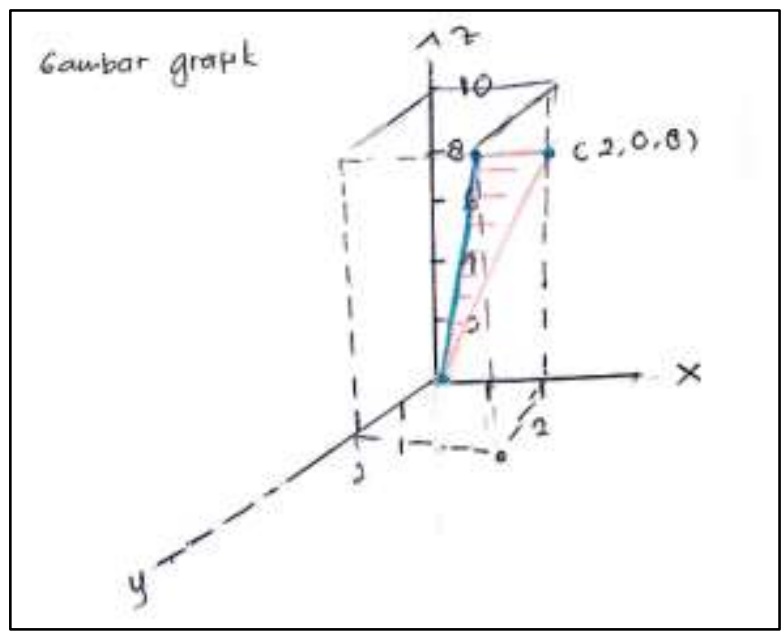

Figure 6. M2's Answer at The Drawing Stage

Figure 6 shows that M2 is quite good at point plotting. The three points plotted are points $(0,0,0),(2,0,8)$, and $(2,2,10)$. There is 1 new point that was not found at the writing stage, namely point $(2,0,8)$ but that point also satisfies the equation $z=2 x+3 y$. M2 draws a graph using the left-hand rule as shown in Figure $7 \mathrm{~b}$ ). This is also permissible, although it is generally agreed that drawing graphs on the Three-Dimensional Cartesian diagram use the right-hand rule as shown in Figure 7a) to obtain a uniform answer. Overall, M2 can graph the multivariable function $z=2 x+3 y$ correctly.

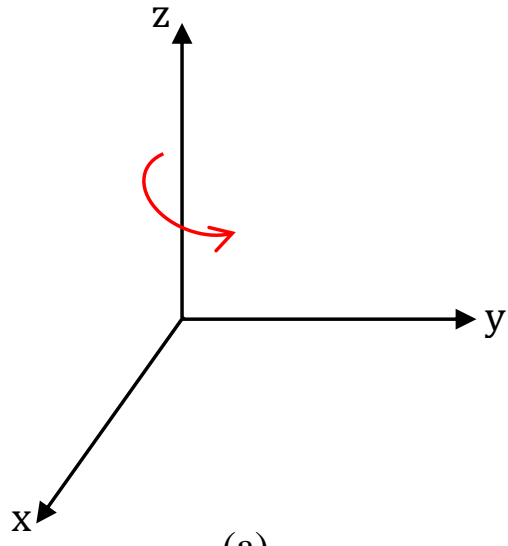

(a)

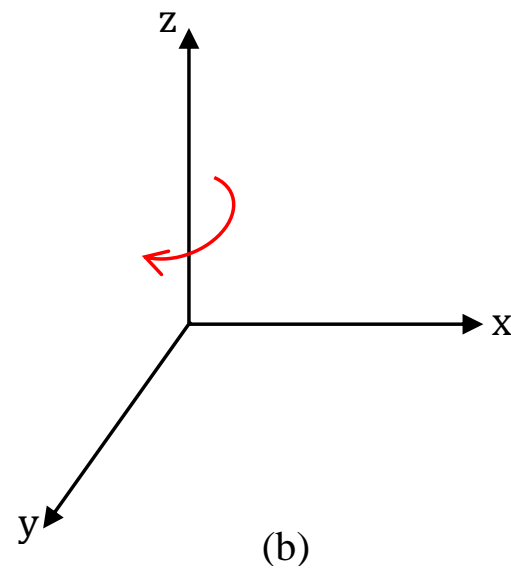

(b)

Figure 7. (a) Right-hand Rule (b) Left-hand Rule

$\mathrm{R}$ : How would you graph the function $\mathrm{z}=2 \mathrm{x}+3 \mathrm{y}$ ?

M2 : First, I draw the $\mathrm{x}$-axis, $\mathrm{y}$-axis, $\mathrm{z}$-axis, and the coordinates of the unit points. Then I plot the points $(0,0,0),(2,0,8)$, and $(2,2,10)$ 
$\mathrm{R}$ : Did you use the right-hand rule or the left-hand rule to draw a threedimensional Cartesian coordinate system?

M2 : I forgot the order, actually, I also know by agreeing to use the right-hand rule but $\mathrm{I}$ put the $\mathrm{x}$ and $\mathrm{y}$ wrong.

$\mathrm{R}$ : Yes, it is okay. Using the left-hand rule is also okay, but so that our answers are all uniform, we agree to use the right-hand rule.

OK... Check again whether you have substituted the three points for $\mathrm{z}=$ $2 \mathrm{x}+3 \mathrm{y}$ ?

M2 : The three points have fulfilled the point, if substituted, I replace the point $(1,2,8)$ with $(2,0,8)$

$\mathrm{R} \quad$ : Why did it change?

M2 : Because when I drew the point, the lines formed almost coincide, so I changed the point.

\subsection{Mathematical Communication Skills Obtained from The Subject of Low Mathematical Abilities}

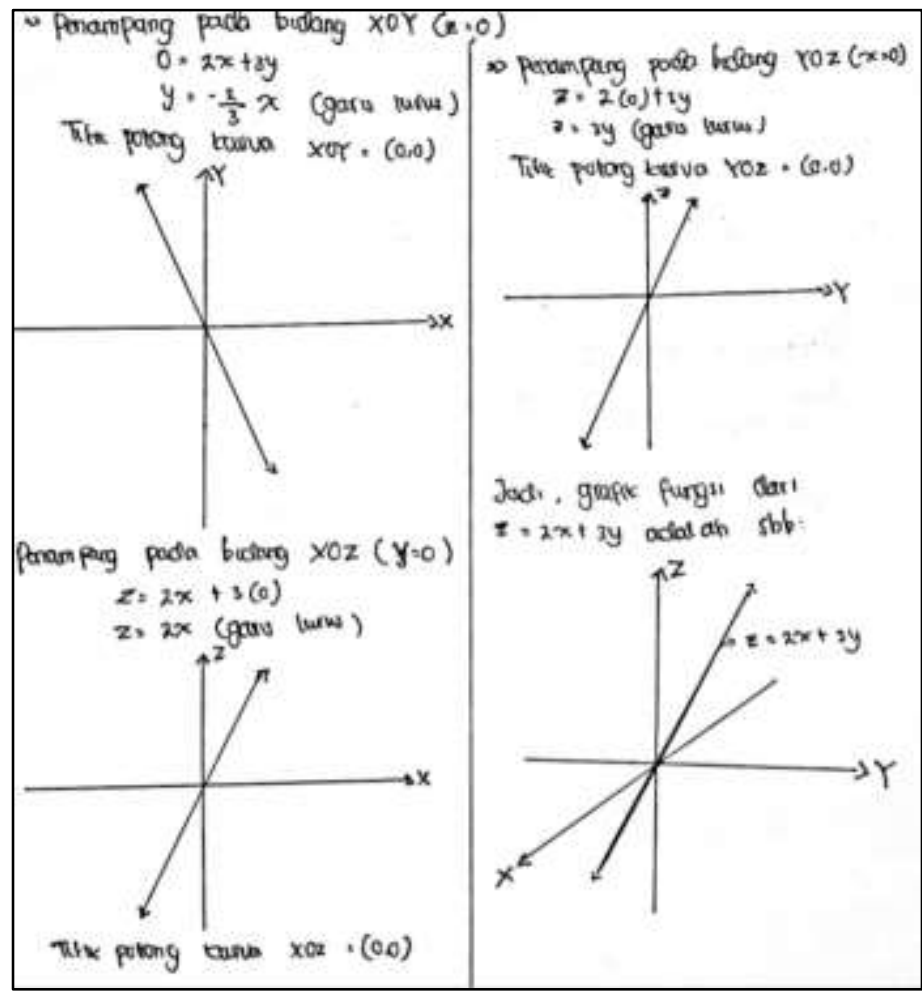

Figure 8. M3's Answer at The Writing and Drawing Stages

Figure 8 shows that M3 cannot formulate the problem well so that the problemsolving strategy chosen is also not right. At the written text stage, M3 is asked to graph the multivariable function $\mathrm{z}=2 \mathrm{x}+3 \mathrm{y}$, but M3 divides it into 3 stages, namely by finding the equation for the resulting line when $\mathrm{x}=0, \mathrm{y}=0$, or $\mathrm{z}=0$ then combining the three the equation that has been obtained and describes the result like the fourth image but the fourth image obtained is also wrong. At the drawing stage, M3 can describe the three equations of the resulting lines but when asked to graph a multivariable function it produces an incorrect answer. While at the stage of making a mathematical model (a mathematical expression), M3 did not make a mistake in operating the algebraic form that was formed 
and there was no mistake in making point substitution, but because the solution strategy is chosen was not correct, the resulting final answer was also incorrect.

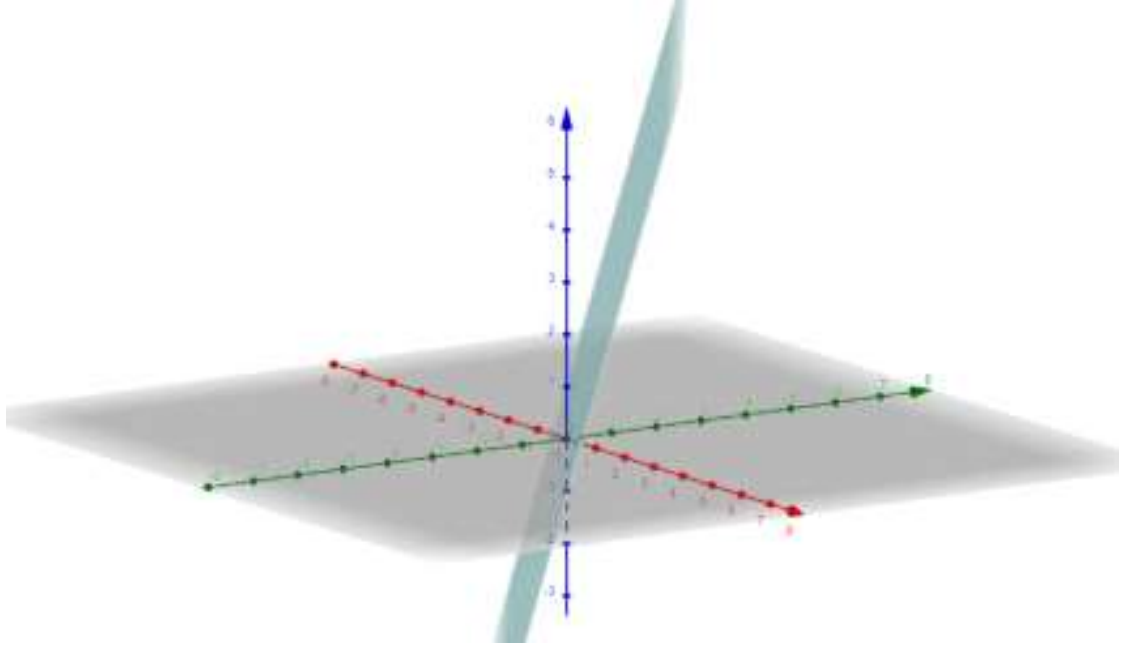

Figure 9. Screenshot of $z=2 x+3 y$ Graph via 3D Geogebra Application

Figure 9 shows the scaffolding assistance to students with the 3D Geogebra application. This application aims to reinforce the answers of M1, M2, and M3 in drawing multivariable graphics because there is a feature of rotating objects so that they can develop students' imagination in drawing multivariable graphs in three-dimensional space.

Thus, the results of this study show that students with high mathematical abilities also have an impact on good communication skills by fulfilling all indicators but make few mistakes due to the rush factor. Meanwhile, students with moderate mathematical abilities tend to have fairly good communication skills on the condition that they have to pay attention to several problem requirements. Meanwhile, students with low math abilities tend to have poor communication skills because they are weak in formulating problems and designing problem-solving strategies. In other words, it can be concluded that students with low communication skills tend to be less good at planning problem solving so that they show wrong results. Another study only uses computer aids in the form of Cabri 3D to help students draw 3D graphics but this study not only using Geogebra's computer aids but also providing scaffolding to students who have low mathematical skills until the correct answer is obtained [25].

\section{CONCLUSION}

The results of this study can be concluded that students' mathematical communication skills with high mathematical abilities have an advantage in the writing stage and making mathematical models, but there are a few errors at the drawing stage, communication skills Mathematical students with moderate mathematical abilities have excellences in all three stages, but there are a few errors in following the agreement which should use the right-hand rule to the left-hand rule, the mathematical communication skills of students with less mathematical abilities, make mistakes in all three stages due to mistakes in formulating problems and designing problem-solving strategies so that the final wrong answer is obtained. For other researchers who want to carry out similar research, it is better if they pay attention to the mathematical communication skills of each student not only based on their mathematical abilities but also in terms of gender, learning style, motivation and interest in learning, and can test this relationship with further experimental research. to obtain significant results. 


\section{REFERENCES}

[1] National Council of Teachers of Mathematics, Principles and Standards for School Mathematics. Reston VA: NCTM, Inc., 2000.

[2] A. Hodge, K. Wanek, and J. Rech, "Tactivities: A tactile way to learn interdisciplinary communication skills," PRIMUS, vol. 30, no. 2, pp. 160-171, 2020.

[3] T. R. Rahmawati, "Kemampuan Komunikasi Matematis Berdasarkan Self-Efficacy Siswa Kelas VII Pada Pembelajaran Arias Bernuansa Etnomatematika." Unnes, 2020.

[4] A. Syukri, J. Marzal, and M. Muhaimin, "Constructivism-Based Mathematics Learning Multimedia to Improve Students' Mathematical Communication Skills," Indones. J. Sci. Math. Educ., vol. 3, no. 2, pp. 117-132, 2020.

[5] V. Syafina and H. Pujiastuti, "Analisis Kemampuan Komunikasi Matematis Siswa pada Materi SPLDV,” MAJU J. Ilm. Pendidik. Mat., vol. 7, no. 2, 2020.

[6] R. K. Rangkuti, W. A. Ritonga, and S. I. Ritonga, "Peningkatan Kemampuan Komunikasi Matematis Melalui Pembelajaran Ekspositori Berbantuan Media Autograph," Al-Khawarizmi J. Pendidik. Mat., vol. 1, no. 1, pp. 7-14, 2020.

[7] R. T. Baroody, Arthur. J., dan Coslick, Problem Solving, Reasoning, and Communicating. New York: Macmillan Publishing, 1993.

[8] H. Hodiyanto, "Kemampuan Komunikasi Matematis Dalam Pembelajaran Matematika," AdMathEdu, vol. 7, no. 1, pp. 9-18, 2017.

[9] A. Qohar, "Pengembangan instrumen komunikasi matematis untuk siswa SMP," in Seminar Nasional Pendidikan Matematika LSM XIX. Yogyakarta: Universitas Negeri Yogyakarta, 2011.

[10] M. Guntur, A. Aliyyatunnisa, and K. Kartono, "Kemampuan Berpikir Kreatif, Kritis, dan Komunikasi Matematika Siswa dalam Academic-Contructive Controversy (AC)," in PRISMA, Prosiding Seminar Nasional Matematika, 2020, vol. 3, pp. 385-392.

[11] R. Rahmalia, H. Hajidin, and B. I. Ansari, "Peningkatan Kemampuan Komunikasi Matematis Dan Disposisi Matematis Siswa SMP Melalui Model Problem Based Learning," Numeracy, vol. 7, no. 1, pp. 137-149, 2020.

[12] A. P. K. and N. K. R. Gita Pratiwi, Faila Sova, Fredi Ganda Putra, Rizki Wahyu Yunian Putra, "The Influence of Project-based Learning (PjBL) and Learning Style om Mathematics Communication Skills of Junior High School Students," J. Phys. Conf. Ser., vol. 1467 (2020, 2020.

[13] U. and H. S. A A Najah, A F Rohmah, "The Implementation of Problem Based Learning (PBL) Model Improving Students' Oral Communication Skill through Lesson Study," J. Phys. Conf. Ser., vol. 1227 01200, 2019.

[14] M. S. N. and E. Rohaeti, "The effect of problem-based learning model toward students' conceptual understanding and verbal communication skills in reaction rate learning," J. Phys. Conf. Ser., vol. 1397 01203, 2019.

[15] S. Fianti, Listiagfiroh, W., "Video tracker analysis: a strategy for measuring students communication and collaboration skills," J. Phys. Conf. Ser., vol. 1567 (2020, 2020.

[16] B. and D. I. E J Apriatna, "The effectiveness of problem-based learning assisted by cabri 3D on student's mathematical communication writing and drawing skills," $J$. Phys. Conf. Ser., vol. 1581, 2020.

[17] N. K. N. Mahadewi, I. M. Ardana, and N. M. S. Mertasari, "Kemampuan Komunikasi Matematis Melalui Model Reciprocal Teaching Berbantuan Media

302 Indonesian Journal of Science and Mathematics Education 
Interaktif," JNPM (Jurnal Nas. Pendidik. Mat., vol. 4, no. 2, pp. 338-350, 2020.

[18] U. M. Rifanti and R. Ananda, "Analisis Kemampuan Komunikasi Matematis Mahasiswa pada Aplikasi Graf Menggunakan Pendekatan MEAs," J. Gantang, vol. 5, no. 2, pp. 113-121, 2020.

[19] T. A. Romberg, Curriculum and evaluation standards for school mathematics. National Council of Teachers of, 1989.

[20] I. Nurahman, "Pembelajaran Kooperatif Tipe Team-Accelerated Instruction (TAI) Untuk Meningkatkan Kemampuan Penalaran dan Komunikasi Matematika Siswa SMP," Pas. J. Math. Educ. J. Pendidik. Mat., vol. 1, no. 1, 2020.

[21] S. A. Hasibuan and S. S. Hasibuan, "Efektivitas Bahan Ajar Matematika Berbasis Budaya Mandailing Dalam Meningkatkan Kemampuan Komunikasi Matematis Siswa," MAJU J. Ilm. Pendidik. Mat., vol. 7, no. 2, 2020.

[22] L. S. Lomibao, C. A. Luna, and R. A. Namoco, "The Influence of Mathematical Communication on Students' Mathematics Performance and Anxiety," Am. J. Educ. Res., 2016.

[23] L. J. Moleong, Metodologi Penelitian Kualitatif (Edisi Revisi). Bandung: Remaja Rosdakarya, 2017.

[24] E. S. Sukaesih, I. Indiati, and F. X. D. Purwosetiyono, "Kemampuan Pemahaman Konsep Matematis Siswa dalam Memecahkan Masalah Kontekstual Ditinjau dari Komunikasi Matematis Siswa," Imajiner J. Mat. dan Pendidik. Mat., vol. 2, no. 4, pp. 310-320, 2020.

[25] U. Khairiyah, D. Idayani, and Y. Puspitasari, "Analisis Kemampuan Komunikasi Matematis Siswa dalam Pemecahan Masalah Matematika Kelas XI MA Darul Ulum," J. Pendidik. dan Kewirausahaan, vol. 8, no. 1, pp. 77-86, 2020. 